Economic Affairs, Vol. 65, No. 1, pp. 85-96, March 2020

DOI: $10.30954 / 0424-2513.1 .2020 .12$

\title{
Performance of Palm Industry in Karnataka: A Case Study in Tumkur District
}

\author{
M.G. Kerutagi $1^{\prime \prime}$, Pavithra, A.S. ${ }^{1}$ and S.G. Gollagi ${ }^{2}$
}

${ }^{1}$ Cost of Cultivation and Market Intelligence Cell, Department of Social \& Allied Sciences, University of Horticultural Sciences, Bagalkot, Karnataka, India

${ }^{2}$ Department of Crop Physiology, University of Horticultural Sciences, Bagalkot, Karnataka, India

*Corresponding author: mgkerutagi@yahoo.com (ORCID ID: 0000-0001-6685-7574)

Received: $22-08-2019$

Revised: 24-01-2020

Accepted: 25-02-2020

\begin{abstract}
The objective of the present study was to analyze the performance of palm industry in Karnataka. The total establishment cost of coconut orchard estimated at ₹ 1,58,842.82 per acre. The annual cost of cultivation of coconut was ₹ 55,933.91 per acre. The total cost incurred in copra making from 5,777.65 nuts (a unit from one acre) estimated at ₹ 69,400.33 and obtained 8.86 quintals of copra. Gross returns obtained from copra making were ₹ $1,17,265.05$. Copra making in the study area is a profitable venture as indicated by B:C ratio (1.68). The study of marketing of copra identified three marketing channels. Producer's share in consumer's rupee was highest (75.02\%) in channel III (Copra makers - Wholesaler - Retailer -Consumers) than channel I and II and considered as efficient marketing channel in the study area. Majority of the copra makers expressed that drastic climate change lead to decrease in production, fluctuation in price of coconut oil was the major marketing problem. The other problem faced by wholesalers was lack of consistent demand and in case of retailers high cost of transportation was the major problems. The copra manufactured in the study area was of good quality. Hence, efforts should made to export the copra. Government can promote artificial dryer unit under cooperative sector and it can provide financial help to construct proper infrastructure for copra making unit. Creating awareness to encourage online trading for better price realization for producers and better quality is the need of the hour.
\end{abstract}

\section{Highlights}

( Copra making is a economically profitable business.

Keywords: Copra making, marketing channel, price spread, marketing efficiency, constraints

Coconut palm, botanically known as "Cocus nucifere" is a unique among the horticultural crops raised in India because of the diverse uses of the coconut products in everyday life. Every part of the coconut tree is having great utility and hence is called as "Kalpavriksha" or the "Tree of Heaven". In India the total area under coconut is 2,082.11 thousand hectares with the production of $23,904.10$ million nuts during 2016-17 (Coconut Development Board). Coconut is the second largest and important horticultural crop of Karnataka state, accounts for 24.67 per cent of area under coconut cultivation and 28.33 per cent of total production of coconut in the country (2016-17).
Karnataka is the major producer of ball copra in the country. In Karnataka both big and small farmers convert the coconut into ball copra particularly in Tumkur, Hassan, Chitradurga and Chikkamagalur districts. There are six APMC markets dealing in ball copra trading. Tiptur APMC is the major ball copra trading centre and the price determined at this market centre will be reflected in the other markets for fixing the trading price. The traditional processing of ball copra is done by storing the well matured coconuts for a period of 11-12 months in

How to cite this article: Kerutagi, M.G., Pavithra, A.S. and Gollagi, S.G. (2020). Performance of palm industry in Karnataka: A case study in Tumkur district. Economic Affairs, 65(1): 85-96. 
the residential building or exclusive store room of the farmers called "ATTA". In the recent days the practice has been developed by the farmers for the construction of godowns exclusively for storing coconut with sufficient air circulation. Nearly 80 per cent of copra from Tiptur is marketed in throughout the country markets like Delhi, Ahmadabad, Kolkata, Pune, Rajasthan, Mumbai, Jaipur, Patna, Nagpur, Cuttack, Indore, Puri and Guwahati (Nagaraju, 2013).

Tiptur taluk in Tumkur district of Karnataka is the traditional coconut growing area endowed with natural advantage and the leading variety is Arasikere tall (local variety). In spite of Kerala producing large quantity but it is not preferred for table purpose and mainly used for extraction of edible oil. Copra grown in and around Tiptur is known for its taste and more popular in the country mainly used for table purpose, sweet preparation and dried fruits. The Tiptur copra is in good demand in Northern India.

Tumkur district is known as the "Kalpatharu Naadu" (land of coconut trees). Majority of the farmers in Tumkur district are dependent primarily on coconut farming for their livelihood. Coconut is grown in all ten taluks of the district, except in some parts of rocky and hilly areas of Madhugiri and Pavagada taluks. However, drought has been affected over the past four years, as coconut trees have been hit by lack of water besides attack of diseases and pests. Hence, farmers are giving up coconut farming altogether and majority turning to non- farming activities. In the light of these, the study makes a modest attempt to investigate the performance of palm industry in Tumkur district of Karnataka state with the following specific objectives:

\section{The specific objectives of the study are:}

1. To estimate the cost and returns structure in coconut farming.

2. To workout out the economics of copra making.

3. To identify the channels of marketing of copra and estimation of price spread.

4. To analyse the marketing efficiency of different marketing channels.
5. To identify the constraints in coconut cultivation, copra making and marketing to provide measures to improve.

\section{Hypothesis of the study}

1. Coconut cultivation and copra making is profitable.

2. There are many channels in copra marketing.

3. Price spread in copra marketing is very high.

4. Many problems are faced in production and marketing of copra.

\section{METHODOLOGY}

The present study was conducted in Tumkur district of Karnataka state during the year 2016-17, as it is highly concentrated in Tumkur district. It ranks first in area $(29.45 \%)$ and production of coconut (32.22\%) in Karnataka state (2015-16). For evaluating the objectives of the study, the required data were collected through personal interview method with the help of a structured schedule. Data pertaining to cost of cultivation of coconut and copra making, the data was collected from 40 farmers randomly. The returns structure of coconut also worked out to compare with the copra returns to know the profitability but in reality producers used coconut in the making of copra. In the process of making of coconut into copra 5,777.65 number of coconut (nuts / acre) were used to make copra. Makers in the study area invested ₹ $18,672.59$ to construct coconut storage unit (low cost). To estimate cost of making of copra, an amortized establishment cost of coconut storage unit worked out was ₹ 622.42. Tiptur taluk is important commercial centre for copra marketing and is more specialized in copra arrivals. Hence, Tiptur market was purposively selected for the study of marketing of copra. For identifying marketing channels, marketing cost, margin and price spread data was collected from various stakeholders like, commission agent (10), village traders (10), wholesalers (10) and retailers (10). Descriptive statistics was employed to analyse the data.

\section{Concepts used}

Copra making unit refers to storing the well matured coconuts for a period of 11-12 months in the store room. The unit consist of an acre of coconut (5,777.65 nuts). 
Amortized establishment cost was calculated from the capital investment made in first 5 years for establishment was divided into equal annual instalments starting from $6^{\text {th }}$ year till the economic life of coconut plantation which was taken as 50 years. To estimate the per acre cost of coconut, an amortized cost was worked out and added in to maintenance cost to estimate the annual cost in cultivation.

Amortization Established Cost $=$

\section{Total Establishment Cost}

Average prodcutive life span of coconut

Marketing channel refers to the alternate routes of product flow from the copra makers to final destiny. There are different channels in copra marketing but the channels which prevail in the domestic market are used for the study.

Marketing cost is the cost incurred by the copra makers-seller for bringing produce from farm gate to sale point in market.

Price spread is worked out by computing the differences between the prices received by the makers and prices paid by the consumer.

Price spread $=\mathrm{Pc}-\mathrm{Pp}$

Where, $\mathrm{Pc}=$ Price paid by the consumer

$\mathrm{Pp}=$ Price received by the makers

\section{Producer's share in consumer's rupee}

It is the price received by the makers expressed as a percentage of the retail price (i.e., the price paid by the consumer). If $\mathrm{Pp}$ is the retail price, the producer's share in consumer's rupee (Ps) may be expressed as follows:

$$
P S=\left(\frac{P F}{P R}\right) * 100
$$

where, PS = Producer's share in consumer's rupee

$\mathrm{PF}=$ Price received by the farmers (copra makers)

$\mathrm{PR}=$ Price paid by the consumer.

\section{Marketing Efficiency by Shepherd's Method}

The marketing efficiency is measured with the help of the formula given by Shepherd.

$$
\mathrm{ME}=\frac{C P}{\Sigma(M C+M M)}
$$

Where, $\mathrm{ME}=$ Marketing efficiency

$\mathrm{CP}=$ Consumer's purchase price

$\mathrm{MC}=$ Marketing cost

$\mathrm{MM}=$ Marketing margins

\section{Marketing Efficiency by Acharya and Agarwal's Method}

The marketing efficiency is measured with the help of the formula given by Acharya and Agarwal i.e.,

$$
\mathrm{ME}=\frac{F P}{(M C+M M)}
$$

Where, ME = Marketing efficiency,

$\mathrm{FP}=$ Price received by farmers (copra makers)

$\mathrm{MC}=$ Marketing cost

$\mathrm{MM}=$ Marketing margins

\section{Garrett's ranking technique}

In order to assess the constraints faced by the coconut producers, copra makers, wholesalers and retailers in making and marketing of copra the Garrett's ranking technique was used to prioritise the constraints. The order of the merits given by the respondents was changed into ranks by using the following formula

$$
\text { Percent position }=100(\mathrm{Rij}-0.5) / \mathrm{Nj}
$$

Where,

$$
\begin{aligned}
& \mathrm{Rij}=\text { rank given for } \mathrm{i}^{\text {th }} \text { factor by } \mathrm{j}^{\text {th }} \text { individual. } \\
& \mathrm{Nj}=\text { number of factors ranked by } \mathrm{j}^{\text {th }} \text { individual } .
\end{aligned}
$$

The percentage position of each rank was converted into scores by referring the table given by Garrett (Garrett and Woodworth, 1969). Then for each factor the scores of individual respondents were added together and divided by the total number of respondents for whom scores were added. These mean scores for all the factors were arranged in descending order and the constraints were ranked. 


\section{RESULTS AND DISCUSSION}

\section{Establishment cost of coconut orchard}

The cost of establishment of coconut orchard up to bearing is broadly classified in to establishment cost and maintenance cost as the coconut orchard starts bearing generally after five years from the year of plantation (Table 1). The cost incurred in a period of five years for establishment of coconut orchard was estimated at ₹ 1,58,842.82 per acre. The establishment cost included not only the costs incurred in initial time of planting but also the cost incurred in maintaining the orchard till the time of bearing. Among the total establishment cost material cost constituted 22.46 per cent ( $₹ 35,673.46$ ) and maintenance cost 77.54 per cent ( $₹ 1,23,169.36)$. The results are in line with the research conducted by Kerutagi et al. (2017) it was revealed that the share of maintenance cost was more than the material cost for establishment of mango orchard in Dharwad district of Karnataka.

Table 1: Investment pattern in coconut orchard in the study area (₹/Acre)

\begin{tabular}{clll}
\hline S1. No & Particulars & Value & Percentage \\
\hline (A) & Investment items & & \\
\hline 1 & Bore well & $22,508.40$ & 14.17 \\
2 & Sprayer & $1,168.00$ & 0.74 \\
3 & Planting material & $10,843.31$ & 6.83 \\
4 & Digging of pit and & $1,153.75$ & 0.73 \\
& planting & & \\
& Sub Total & $35,673.46$ & 22.46 \\
\hline (B) & Maintenance cost up to bearing period \\
\hline 1 & Ist year & $28,551.32$ & 17.97 \\
2 & II ${ }^{\text {nd }}$ year & $26,477.98$ & 16.67 \\
3 & III ${ }^{\text {rd }}$ year & $23,873.82$ & 15.03 \\
4 & IV ${ }^{\text {th }}$ year & $22,367.47$ & 14.08 \\
5 & $V^{\text {th }}$ year & $21,898.77$ & 13.79 \\
& Sub Total & $1,23,169.36$ & 77.54 \\
& (I+II+III+IV+V) & \multicolumn{2}{l}{} \\
\hline & Total Establishment & $1,58,842.82$ & 100.00 \\
& Cost (A+B) & & \\
\hline
\end{tabular}

A perusal of Table 2 reveals that maintenance cost as indicated in the results included the wages of labour, material cost which were utilized during maintenance period. The maintenance cost incurred during gestation period was $₹ 1,23,169.36$. It was noticed that out of total maintenance cost the major component was variable cost $(70.29 \%)$ followed by fixed cost $(29.71 \%)$. Among the total variable cost (₹ 86,576.86), the labour cost formed an important cost accounting to 29.58 per cent, since the crops require labour involvement to prefer the important activity like formation of basin around the plants, application of manure and fertilizer etc. Among the material cost the major components are fertilizer ₹ $17,721.94(20.47 \%)$ and manure ₹ $13,981.80$ $(16.15 \%)$ others are accounted to percentage. Out of total maintenance cost 23.18 per cent ( $₹ 28,551.32)$ was incurred during the first year, 21.50 per cent ( $₹$ $26,477.98$ ) in second year, 19.38 per cent (₹ 23,873.82) in third year, 18.16 per cent ( $₹ 22,367.47$ ) in fourth year and 17.78 per cent ( $₹ 21,898.77$ ) in fifth year. Maximum expenditure was incurred during the first year and relatively lesser expenditure in subsequent years. The findings are similar to the results of the research conducted by Srinivas (1989).

Maintenance cost of coconut orchard during bearing period presented in Table 3. Total cost of cultivation of coconut per acre was ₹ 55,933.91 of which share of variable cost was 70.55 per cent and fixed cost was 29.45 per cent. The similar results were observed in research conducted by Hasna Hassan (2010) reported that the total cost of production of per acre of arecanut, the share of variable cost was more than the fixed cost. In the present study, proportion of variable cost was ₹ 39,459.95 which was actual paid out cost by the farmers. Among the variable cost, the share of human labour cost was maximum ₹ $13,423(34.02 \%)$ followed by fertilizer cost ₹ 9,529.00 (24.15\%) and FYM cost ₹ 4,172 (10.57\%) and others are accounted to percentage. Human labour cost was higher compared to other operational cost items, the results are in line with the earlier study conducted by Vinodhini et al. (2017). Total fixed cost was ₹ 16,473.96, of the fixed cost, the share of major cost items were rental value of land accounted to ₹ 6,147.18 (37.31\%) followed by managerial cost ₹ 4,643.61 (28.19\%) and amortized establishment cost ₹ $3,176.85(19.28 \%)$ these were the major cost items of fixed cost.

\section{Cost and returns from coconut enterprise}

It was observed from Table 4 that the average quantity of coconuts obtained from an acre was $5,777.65$ nuts. Cost of production of coconut incurred over total and paid out cost was ₹ 9.68 per nut and ₹ 6.82 per nut respectively. These results are 
Table 2: Maintenance cost of coconut orchard during gestation period in the study area (₹/Acre)

\begin{tabular}{|c|c|c|c|c|c|c|c|}
\hline \multicolumn{2}{|c|}{ Sl. No Particulars } & $I^{\text {st }}$ year & II $^{\text {nd }}$ year & III $^{\text {rd }}$ year & IV $^{\text {th }}$ year & $\mathbf{V}^{\text {th }}$ year & Total \\
\hline 1 & Land preparation & $1,766.25$ & - & - & - & - & $1,766.25(1.43)$ \\
\hline 3 & Preparation of basin & 834.25 & 881.25 & 883.60 & 897.7 & 940.67 & $4,437.47(3.60)$ \\
\hline 4 & Soil application & 840.00 & $1,125.00$ & - & - & - & $1,965.00(1.60)$ \\
\hline 5 & Application of manure & 989.56 & $1,045.31$ & $1,109.20$ & $1,118.60$ & $1,172.15$ & $5,434.82(4.41)$ \\
\hline 8 & PPC spraying & 355.00 & 487.50 & 526.40 & 564.00 & 591.00 & $2,523.90(2.05)$ \\
\hline \multirow[t]{2}{*}{9} & Irrigation & 102.06 & 145.31 & 150.40 & 157.60 & 172.37 & $727.74(0.59)$ \\
\hline & Total Labour Cost & $6,254.12$ & $5,367.97$ & $4,820.15$ & $4,658.65$ & $4,511.87$ & $25,612.76(20.79)$ \\
\hline B & Material Cost & & & & & & \\
\hline 1 & Seedling for gap & - & 161.79 & 496.00 & 406.44 & - & $1,064.23(0.86)$ \\
\hline 6 & Neem cake & 705.19 & 891.77 & 890.95 & 442.42 & 527.27 & $3,457.60(2.81)$ \\
\hline \multirow[t]{4}{*}{7} & Repairing of bore well & - & $1,148.91$ & $1,912.55$ & $2,049.78$ & - & $5,111.24(4.15)$ \\
\hline & Total Material Cost & $11,457.85$ & $11,444.90$ & $9,625.31$ & $8,417.40$ & $8,138.09$ & $49,083.55(39.85)$ \\
\hline & Managerial Cost (10\% of TC) & $3,520.85$ & $2,346.61$ & $2,109.86$ & $1,972.92$ & $1,930.31$ & $11,880.55(9.65)$ \\
\hline & Total Variable cost & $21,232.82$ & $19,159.48$ & $16,555.32$ & $15,048.97$ & $14,580.27$ & $86,576.86(70.29)$ \\
\hline II & Fixed Cost & & & & & & \\
\hline 1 & Rental value of land & $6,147.18$ & $6,147.18$ & $6,147.18$ & $6,147.18$ & $6,147.18$ & $30.735 .90(24.95)$ \\
\hline 2 & Land tax & 10.00 & 10.00 & 10.00 & 10.00 & 10.00 & $50.00(0.04)$ \\
\hline 3 & Depreciation & 496.00 & 496.00 & 496.00 & 496.00 & 496.00 & $2,480.00(2.01)$ \\
\hline 4 & Interest on fixed capital @ 10\% & 665.32 & 665.32 & 665.32 & 665.32 & 665.32 & $3,326.59(2.70)$ \\
\hline \multicolumn{2}{|c|}{ Total Fixed Cost } & $7,318.50$ & $7,318.50$ & $7,318.50$ & $7,318.50$ & $7,318.50$ & $36,592.50(29.71)$ \\
\hline
\end{tabular}

Figures in the parentheses indicates percentage of the total.

Table 3: Maintenance cost of coconut orchard during bearing period (VI year onwards) in the study area (₹/Acre)

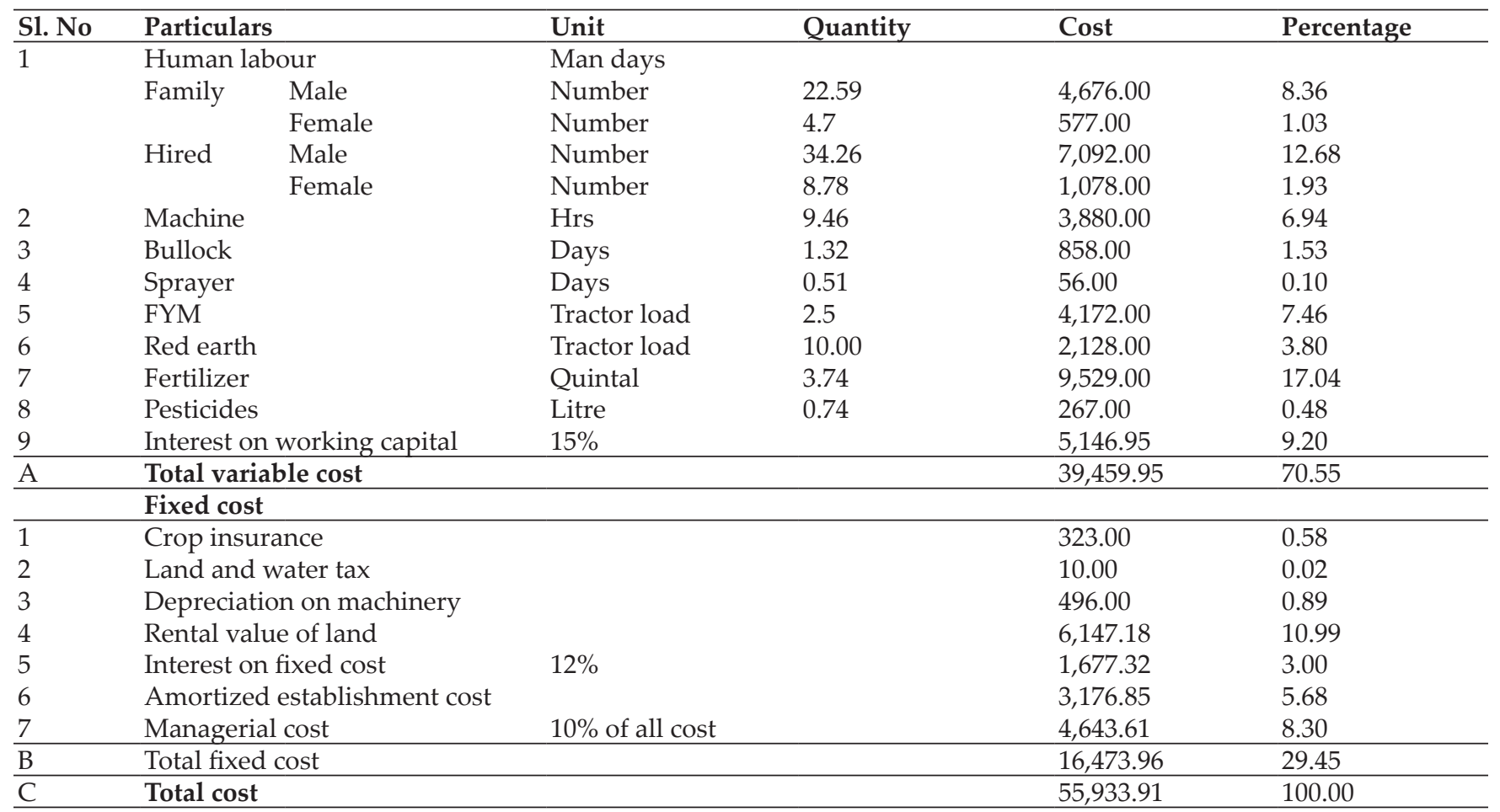


higher than the earlier study conducted by Sairam et al. (1997), it was revealed that cost of production of coconut was ₹ 3.30 and ₹ 2.60 per nut. Gross returns received by selling main and by product were $₹$ 45,017.09 (main product $₹ 44,199.02$ at a price of 7.65 per nut and by-product 818.07 at a price of 737 per tractor load). This indicated that returns from main produce 98.18 per cent and remaining 1.81 per cent of returns obtained from by-products of coconut tree. These results are same with the results of the study conducted by Vinodhini et al. (2017). B:C ratio of the coconut production was 0.80 which is less than unity. Due to monsoon failure, lack of irrigation facilities and less market price they incurred loss in coconut production. It was observed in earlier study conducted by Kishore et al. (2017) reported that $\mathrm{B}: \mathrm{C}$ ratio of the coconut was 1.18 which is higher than the present study. It was witnessed that due to monsoon failure in the study area was the major drawback to realize negative returns otherwise coconut farming is profitable venture.

Table 4: Economics of coconut enterprise in the study area (₹/Acre)

\begin{tabular}{|c|c|c|}
\hline $\begin{array}{l}\text { Sl. } \\
\text { No }\end{array}$ & Particulars & Amount (₹) \\
\hline \multirow[t]{2}{*}{1} & $\begin{array}{l}\text { Cost of production of coconut (₹/ } \\
\text { Acre) }\end{array}$ & $55,933.91$ \\
\hline & $\begin{array}{l}\text { (A) Returns from main product } \\
\text { (5,777.65 No.s @ ₹ } 7.65 \text { /nut ) }\end{array}$ & $44,199.02$ \\
\hline \multirow[t]{2}{*}{2} & $\begin{array}{l}\text { (B) Returns from by-product } \\
\text { (1.11TL @ ₹ } 737 \text { /TL) }\end{array}$ & 818.07 \\
\hline & Gross returns $(\mathrm{A}+\mathrm{B})$ & $45,017.09$ \\
\hline 3 & Net profit & -10.916 .82 \\
\hline 4 & $\begin{array}{l}\text { Cost of production over total cost } \\
\text { (₹/Nut) }\end{array}$ & 9.68 \\
\hline 5 & $\begin{array}{l}\text { Cost of production over paid out } \\
\text { cost (₹/Nut) }\end{array}$ & 6.82 \\
\hline 6 & $\mathrm{~B}: \mathrm{C}$ ratio & 0.80 \\
\hline
\end{tabular}

It was observed during the study coconut trees have been hit by lack of water due to monsoon failure even ground water also depleted this was the major drawback for producers to incurred loss in coconut production. However, to overcome this problems producer should implement drip irrigation for coconut orchard is the best method to use available water in efficient way to improve the crop heath to increase yield of coconut.

Table 5 depicts that the time required to convert coconut in to copra was 12 months. The total cost incurred for copra making from 5,777.65 numbers of coconuts estimated was ₹ $69,400.33$, out of which variable cost accounted to ₹ 68,703.22 (99.00\%) and share of fixed cost was ₹ 697.11 (1.00\%). Among the variable cost raw coconut cost was more which was ₹ $55,933.91(81.41 \%)$, cost of production of coconut was taken as raw coconut cost, followed by interest on working capital was ₹ 8,961.29 (13.04\%) worked out at 15 per cent and labour cost was ₹ $3,808.02(5.54 \%)$. The results revealed that human labour involvement in copra making is an important variable cost. Among the fixed cost share of amortization cost was higher ₹ 622.42 (89.29\%) and interest on fixed cost was ₹ 74.69 (10.71). Similar findings were observed in the research conducted by Kakkali (2013).

Table 5: Cost of structure in copra making in the study area

\begin{tabular}{|c|c|c|c|}
\hline \multirow{2}{*}{\multicolumn{4}{|c|}{$\begin{array}{l}\text { Sl. } \\
\text { No. } \\
\text { Varticulars } \\
\end{array}$}} \\
\hline & & & \\
\hline \multirow[t]{2}{*}{1} & Raw coconut & $55,933.91$ & 80.60 \\
\hline & Labour charge & & \\
\hline 2 & Drying of coconut & 785.06 & 1.13 \\
\hline 3 & Removing of husk & $2,311.06$ & 3.33 \\
\hline \multirow[t]{3}{*}{4} & $\begin{array}{l}\text { Breaking and removing the } \\
\text { shell from the nuts }\end{array}$ & 711.90 & 1.03 \\
\hline & Sub total & $3,808.02$ & 5.49 \\
\hline & $\begin{array}{l}\text { Interest on working capital } \\
(15 \%)\end{array}$ & $8,961.29$ & 12.91 \\
\hline \multirow[t]{2}{*}{ A } & Total variable cost & $68,703.22$ & 99.00 \\
\hline & Fixed cost & & \\
\hline 1 & Amortized establishment cost & 622.42 & 0.90 \\
\hline 2 & Interest on fixed cost $(12 \%)$ & 74.69 & 0.11 \\
\hline B & Total fixed cost & 697.11 & 1.00 \\
\hline C & Total cost & $69,400.33$ & 100.00 \\
\hline
\end{tabular}

Economics of copra making shown in Table 6 it was revealed that 8.86 quintal of copra and 1.11 tractor load of by-product obtained from 5,777.65 nuts. Cost incurred in copra making over total cost was ₹ 7,740.66 per quintal. Gross returns received by selling of 8.86 quintal of copra ( $₹ 1,16,446.98$ at a price of $₹ 13,143.00$ per quintal) and 1.11 tractor load of by-product (₹ 818.07 at a price of ₹ 737 per tractor load) was ₹ $1,17,265.05$. The net returns obtained were $₹ 47,864.72$. The results revealed that copra making in the study area is a profitable venture as indicated by benefit cost ratio (1.68). 
These results indicated that the profit earned by selling of copra is better than selling of coconut. The earlier study conducted by Venkat Reddy et al. (2017) reported that the $\mathrm{B}: \mathrm{C}$ ratio of the coconuts per acre was 1.23 which is lesser than the $\mathrm{B}: \mathrm{C}$ ratio of copra in the present study. In another study carried out by Murthy (1999) and Remold (2000) reported that $\mathrm{B}: \mathrm{C}$ ratio was 1.38 and 1.01 respectively. These results witnessed that copra making is economically profitable business compared to selling of coconut.

It was observed during the study most of the producers in the study area were selling coconut immediate harvest due to meet their financial need. However, some of the producers were making copra by storing coconut for a year to receive good returns for their produce. The results showed that the selling of copra is better than the selling of coconut is due to assess of higher returns in selling of copra.

Table 6: Economics of copra making in the study area

\begin{tabular}{lll}
\hline $\begin{array}{l}\text { S1. } \\
\text { No }\end{array}$ & Particulars & Amount (₹) \\
\hline 1 & $\begin{array}{l}\text { Cost of making of copra (₹/ 5777.65 } \\
\text { nuts) }\end{array}$ & $69,400.33$ \\
2 & $\begin{array}{l}\text { (A) Returns from copra (8.86 Qtl @ ₹ } \\
\text { 13,143/Qtl) }\end{array}$ & $1,16,446.98$ \\
& $\begin{array}{l}\text { (B) Returns from by-product (1.11TL @ } \\
\text { ₹ 737 /TL) }\end{array}$ & \\
& Gross returns (A+B) & $1,17,07$ \\
3 & Net return & $47,864.72$ \\
4 & Returns per quintal of copra & $13,143.00$ \\
5 & Cost of making of copra (₹/Qtl) over & $7,740.66$ \\
& total cost & \\
6 & Cost of making of copra (₹/Qtl) over & $7,661.98$ \\
& paid out cost & 1.68 \\
7 & B:C ratio &
\end{tabular}

\section{Marketing of copra}

The marketing of copra was studied in Tiptur market because this is the major copra market in Karnataka.

\section{Channels involved in marketing of copra}

It was observed during the study, in the process of marketing of copra, commission agent, village trader, wholesaler and retailers are the important intermediaries. Further, in the marketing of copra following three different marketing channels were observed in the study area and presented in Fig. 1.
1. Copra makers $\rightarrow$ Commission agent $\rightarrow$ Wholesaler $\rightarrow$ Retailer $\rightarrow$ Consumer

2. Copra makers $\rightarrow$ Village trader $\rightarrow$ Commission agent $\rightarrow$ Wholesaler $\rightarrow$ Retailer $\rightarrow$ Consumer

3. Copra makers $\rightarrow$ Wholesaler $\rightarrow$ Retailer $\rightarrow$ Consumer

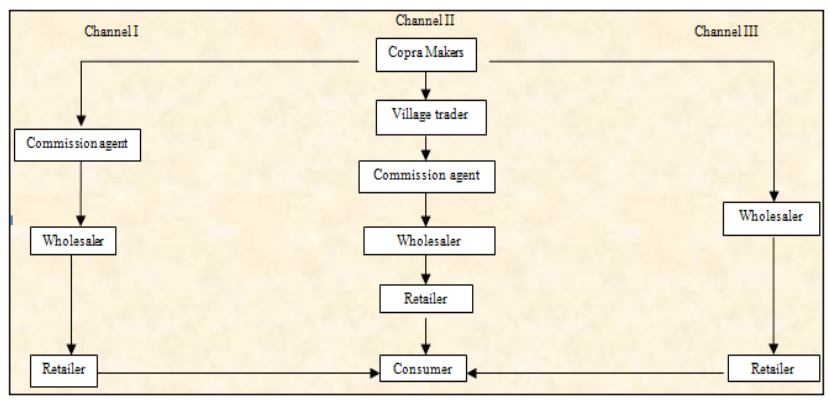

Fig. 1: Map of copa marketing channel in the study area

The copra makers in the study area sold their produce through different marketing channels. The cost incurred by them in marketing of one quintal of copra through different marketing channels was worked out and these are presented in Table 7 and Fig. 2.

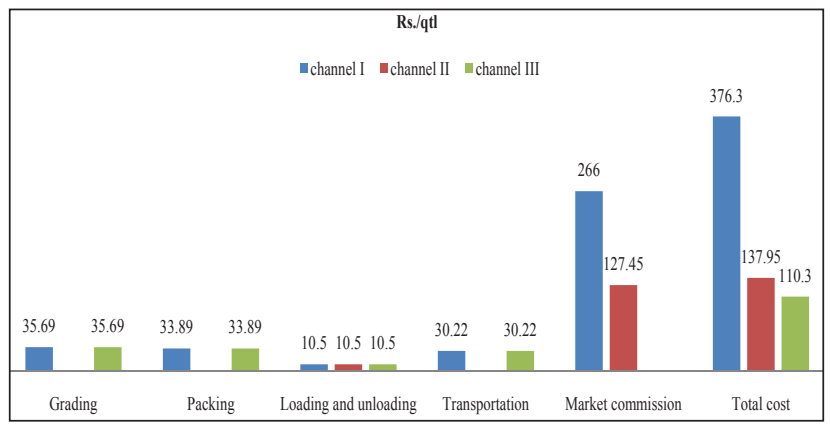

Fig. 2: Marketing cost of copra incurred by copra makers

The cost incurred by the copra makers in marketing of one quintal of copra estimated (Table 7) at ₹ 376.30 in channel I, ₹ 137.95 in channel II and ₹ 110.30 in channel III respectively. Among the various costs items in marketing of copra in Channel I, market commission $(70.69 \%)$, grading $(9.48 \%)$ and packing $(9.01 \%)$ had a major share in total marketing cost. Market commission charges occupy major share in Channel II (92.39\%) of the total marketing cost, followed by loading and unloading charges $(7.61 \%)$. The grading, packing and transportation charges occupy more shares in channel III and together constitute 90.48 per cent and loading and unloading charges 9.51 per cent of 
Table 7: Marketing cost of copra incurred by copra makers (₹/qtl)

\begin{tabular}{llllllll}
\hline \multirow{2}{*}{ S1. No } & \multirow{2}{*}{ Particulars } & Channel I & \multicolumn{3}{c}{ Channel II } & Channel III \\
\cline { 2 - 7 } & Cost (₹/qtl) & $\%$ & Cost (₹/qtl) & $\%$ & Cost (₹/qtl) & \% \\
\hline 1 & Grading & 35.69 & 9.48 & - & - & 35.69 & 32.35 \\
2 & Packing & 33.89 & 9.01 & - & - & 33.89 & 30.72 \\
3 & Loading and unloading & 10.50 & 2.79 & 10.50 & 7.61 & 10.50 & 9.51 \\
4 & Transportation & 30.22 & 8.03 & - & - & 30.22 & 27.39 \\
5 & Market commission & 266.00 & 70.69 & 127.45 & 92.39 & - & - \\
\hline & Total marketing cost & 376.30 & 100.00 & 137.95 & 100.00 & 110.30 & 100.00 \\
\hline
\end{tabular}

the total marketing cost. These results revealed that channel III was incurred less marketing cost than other channels in the study area. Similar results were observed in the study conducted by Narendra Kumar (2017) on study of marketing of coconut in Raigad district of Maharashtra state.

\section{Price spread in copra marketing}

The costs incurred and margin earned by the various market intermediaries, in different channel, in the process of marketing of copra per quintal, in the study area are presented in Table 8 .

The price spread in the marketing channel I (Table 8) copra maker was selling produce through commission agent to wholesaler then it move to retailers to consumers. Copra makers incurred marketing cost for selling of copra was ₹ 376.30 per quintal and received net amount $₹ 12,923.70$ against the market price ₹ 13,300.00 per quintal. Marketing cost received by the commission agent, wholesalers and retailers was ₹ 319.20, ₹ 365. 08 and ₹ 335.07 per quintal respectively. Among the intermediaries, retailers earned profit margin ₹ $2,439.98$ per quintal and they sold produce to consumer at the price of $₹ 17,693.48$ per quintal. The price spread worked out was ₹ 4,769.78 per quintal and producer's share in consumer's rupee was 73.04 per cent of the consumer price with a net price ₹ $12,923.70$ per quintal. The rest 26.96 per cent was comprised of marketing cost and profit margin of the market functionaries.

Further, it was observed from the Table 8 that the price spread in the marketing channel II. In this channel village trader approaches the copra makers or copra makers approaches the village trader for marketing of copra. The village trader sell the produce to wholesalers through commission agent, then produce move through retailers to consumers.
Price spread in the marketing channel was ₹ 5,086.43 which was more than the channel I. copra makers received net price $₹ 12,607.05$ against market price ₹ $12,745.00$ per quintal. Among the stakeholders wholesalers incurred more marketing cost ₹ 363.96 compared to village trader $₹ 330.74$, commission agent $₹ 330.81$ and retailers $₹ 335.07$ per quintal of copra in the study area. Marketing cost incurred in this channel was more compared to other channels in the study area was due to presence number of intermediaries. The marketing cost worked out was more for this channel for coconut in Raigad district of Maharashtra (Narendra Kumar, 2017). Producer's share in consumer's rupee was 71.25 per cent of the consumer price with a net price ₹ $12,607.05$ per quintal. The rest 28.75 per cent was comprised of marketing cost and profit margin of the market functionaries.

Price spread in marketing channel III (Table 8) revealed that this was the shortest marketing channel identified in the study area. Copra makers sell copra directly to wholesalers and it move through retailers to consumers. Copra makers received net price $₹ 13,274.00$ per quintal against market price ₹ $13,385.00$ and they incurred less marketing cost (₹ 110.30 per quintal) compared to other stakeholders. Producer's share in consumer's rupee was 75.02 per cent of consumer price with a net price ₹ 13,274.70 per quintal which was higher than the channel I and II. Namasivayam et al. (2006) conducted study on the price spread in marketing of coconut in Tamil Nadu with the reference to Theni district, it was revealed that producer's share in the consumer's rupee was the maximum in this channel (Producer $\rightarrow$ wholesaler $\rightarrow$ retailer $\rightarrow$ consumers) than other marketing channels in the study area.

Price spread analysis showed that, channel I is best from copra maker's point of view. However, copra 
makers prefer wholesalers between channel I and II, channel III is more profitable to copra makers due to price spread in this channel was less (₹ 4,418.78 per quintal) because of less marketing cost and higher producer's price among the other marketing channels. The results of the study is in line with the study conducted by Mabel Sulochana (2009).

Table 8: Price spread in marketing channels in the study area $(₹ / \mathrm{qtl})$

\begin{tabular}{llll}
\hline Sl. Particulars & Channel- & Channel Channel \\
No & I & -II & -III \\
\cline { 2 - 3 } & Amount & Amount & Amount \\
\hline
\end{tabular}

1 Price of copra received 13,300.00 12,745.00 13,385.00 by copra makers

2 Marketing Charges incurred by copra makers

Grading

Packing

Loading \& unloading

Transportation

Commission charges

3 Total marketing charges incurred by

the copra makers

4 Net amount received by copra makers

5 Marketing charges incurred by village trader

\begin{tabular}{|c|c|c|c|}
\hline Purchase price & - & $12,745.00$ & - \\
\hline Packing & - & 64.50 & - \\
\hline Transportation & - & 42.50 & - \\
\hline Loading \& unloading & - & 10.00 & - \\
\hline Grading & - & 22.57 & - \\
\hline Commission charges & - & 191.17 & - \\
\hline $\begin{array}{l}\text { Total marketing } \\
\text { charges incurred by } \\
\text { the village trader }\end{array}$ & - & 330.74 & - \\
\hline $\begin{array}{l}\text { Marketing margin of } \\
\text { the village trader }\end{array}$ & - & 487.50 & \\
\hline Sale price & - & $13,232.50$ & - \\
\hline $\begin{array}{l}\text { Marketing charges } \\
\text { incurred by the } \\
\text { commission agent }\end{array}$ & & & - \\
\hline Purchase price & $13,300.00$ & $13,232.50$ & - \\
\hline Commission & 319.20 & 330.81 & - \\
\hline Sale price & $13,619.20$ & $13,563.31$ & - \\
\hline \multicolumn{4}{|l|}{$\begin{array}{l}\text { Marketing charges } \\
\text { incurred by the } \\
\text { wholesaler }\end{array}$} \\
\hline Purchase price & $13,619.20$ & $13,563.31$ & $13,385.00$ \\
\hline Commission charge & 272.38 & 271.26 & 267.7 \\
\hline $\begin{array}{l}\text { Loading and } \\
\text { unloading }\end{array}$ & 11.20 & 11.20 & 11.20 \\
\hline
\end{tabular}

\begin{tabular}{|c|c|c|c|c|}
\hline & Packing & 47.00 & 34.50 & 47.00 \\
\hline & Transportation & 34.50 & 47.00 & 34.50 \\
\hline 8 & $\begin{array}{l}\text { Total marketing } \\
\text { charges incurred by } \\
\text { the wholesaler }\end{array}$ & 365.08 & 363.96 & 360.4 \\
\hline 9 & $\begin{array}{l}\text { Marketing margin of } \\
\text { the wholesaler }\end{array}$ & 1634.30 & 1690.19 & 1868.5 \\
\hline 10 & Wholesaler price & $15,253.50$ & $15,253.50$ & $15,253.50$ \\
\hline 11 & \multicolumn{4}{|c|}{ Marketing charges incurred by the retailer } \\
\hline & Purchase price & $15,253.50$ & $15,253.50$ & $15,253.50$ \\
\hline & $\begin{array}{l}\text { Loading and } \\
\text { unloading }\end{array}$ & 11.60 & 305.07 & 11.60 \\
\hline & Commission charges & 305.07 & 11.60 & 305.07 \\
\hline & Transportation & 18.40 & 18.40 & 18.40 \\
\hline 12 & $\begin{array}{l}\text { Total marketing cost } \\
\text { incurred by the retailer }\end{array}$ & 335.07 & 335.07 & 335.07 \\
\hline 13 & $\begin{array}{l}\text { Marketing margin of } \\
\text { the retailer }\end{array}$ & 2439.98 & 2439.98 & 2439.98 \\
\hline 14 & Consumer price & $17,693.48$ & $17,693.48$ & $17,693.48$ \\
\hline 15 & Total marketing cost & 1395.45 & 1498.53 & 805.77 \\
\hline 16 & $\begin{array}{l}\text { Total marketing } \\
\text { margin }\end{array}$ & 4074.28 & 4617.67 & 4308.48 \\
\hline 17 & Price spread & 4769.78 & 5086.43 & 4418.78 \\
\hline 18 & $\begin{array}{l}\text { Producer's share in } \\
\text { consumer's rupee }\end{array}$ & 73.04 & 71.25 & 75.02 \\
\hline
\end{tabular}

These results witnessed that existence of more number of intermediaries in the marketing channel accounted higher price spread it leads copra makers to receive less net price. Selling of copra directly to wholesalers is profitable but it was perceived by very few copra makers in the study area. Maximum number of copra makers sold copra to commission agent or village traders because of lack of knowledge of market information, so that it is necessary to provide market information to copra makers to select best market channel. Government should encourage online trading of copra to avoid middleman activities in marketing, it helps to reduce marketing cost and increase producer's share in consumer's rupee and also it helps to reduce the price spread by shortening the marketing channel.

Marketing efficiency: Marketing efficiency of the different marketing channels was studied by using Shepherd's method and Acharya and Agarwal method is presented in Table 9.

The results presented in the Table 9 revealed that in case of Shepherd's method, among the three channels, channel III was observed to be efficient marketing channel for copra in the study area. The efficiency index for channel III was the maximum with 3.46 followed by channel I was 3.23. Further, it 
is also observed from table indicated that marketing efficiency analysis using Acharya and Agarwal method. Marketing efficiency index of channel III (2.60) was greater than that of channel I (2.36) and channel II (2.06) for copra marketing. Because of less marketing charges incurred in channel III marketing efficiency was more than other channels in the study area. The research conducted by Namasivayam et al. (2006 ) revealed that the marketing efficiency was higher in channel III (similar to marketing channel III in the present study) compared to other channels. In another research carried out by Sulthan Mohideen et al. (2016) reported that the marketing efficiency is greater in this channel Growers wholesalers -retailers -consumers for mango in Theni district of Tamilnadu.

Table 9: Marketing efficiency analysis using shepherd's and Acharya and Agarwal Method (₹/qtl)

\begin{tabular}{llll}
\hline Particulars & $\begin{array}{l}\text { Channel } \\
\text { I }\end{array}$ & $\begin{array}{l}\text { Channel } \\
\text { II }\end{array}$ & $\begin{array}{l}\text { Channel } \\
\text { III }\end{array}$ \\
\hline $\begin{array}{l}\text { Price received by the } \\
\text { copra makers }\end{array}$ & $13,300.00$ & $12,745.00$ & $13,385.00$ \\
$\begin{array}{l}\text { Net price received by the } \\
\text { copra makers }\end{array}$ & $12,923.70$ & $12,607.05$ & $13,274.70$ \\
$\begin{array}{l}\text { Consumer's purchase } \\
\text { price (CP) }\end{array}$ & $17,693.48$ & $17,693.48$ & $17,693.48$ \\
$\begin{array}{l}\text { Marketing cost (MC) } \\
\text { Marketing margins (MM) }\end{array}$ & $1,395.45$ & $1,498.53$ & 805.77 \\
$\begin{array}{l}\text { ME (Shepherd's method) } \\
\text { ME (Acharya and }\end{array}$ & 3.23 & $4,617.67$ & $4,308.48$ \\
Agarwal method) & 2.36 & 2.89 & 3.46 \\
\hline
\end{tabular}

\section{Constraints in coconut cultivation, copra making and marketing in the study area}

Constraints faced by producers in coconut and copra making are presented in Table 10 and marketing constraints faced by copra makers, wholesalers and retailers are presented in Table 11.

Major constraints faced by producers in coconut production were incidence of pest and diseases. Monsoon failure leads to reduction in the yield due to lack of irrigation facility, so that water problem was opined as the second vital problem followed by shortage of tree climber during harvesting time and financial problems were considered as major problems in coconut cultivation. Climatic condition, high cost of inputs and labour problems were least expressed by the producers.
Further, it was observed from the Table 10 indicates that constraints faced by copra makers. It was noticed that monsoon failure during the study, as production of copra depends on production of coconut. Due to poor and unfavourable climatic condition the coconut production is affected. Hence climatic condition and decreasing production was ranked first and second respectively. Due to lack of irrigation in the study area poor quality of copra was obtained so that poor quality of produce ranked third. The conversion of coconut into copra is a time consuming process (12 months required), so copra makers have to wait so long to get returns this was quite problematic in case of marginal and small farmers because of their financial requirement to meet their needs. Even though selling of copra receiving more profit than selling of coconut due to financial problems of the farmers tends to sell some portion coconut so that financial problems ranked fourth. Lack of knowledge of new technology, lack of proper infrastructure for copra making and labour problem was least expressed by the copra makers.

Marketing constraints faced by copra makers were that majority of the respondents expressed that the problem in fluctuation of price followed by world price of coconut oil, bullish pattern, exploitation of middle man and high cost of transportation in the study area (Table 11). It was observed that most of the producers expressed lack of market information and inadequate storage facility were the minor problems faced by the copra makers in the study area.

Constraints faced by the wholesalers (Table 11) opined that fluctuation in market price, lack of consistent demand and high commission charges were considered as major problems. Lack of infrastructure facilities in the market, high cost of transportation, poor quality of produce and lack of market information were the minor problems faced by the wholesalers in the study area.

It was evident that fluctuation in price was reported as major constraint faced by wholesalers due to varied production of copra over a year and world price of coconut oil influences on price of copra. During the festival season copra demand will be more than normal days so that demand is inconsistent. 
Table 10: Constraints faced by the coconut producers and copra makers in the study area

\begin{tabular}{|c|c|c|c|c|c|c|}
\hline \multicolumn{4}{|c|}{ Coconut production constraints } & \multicolumn{3}{|c|}{ Copra making constraints } \\
\hline S1. No & Particulars & $\begin{array}{l}\text { Mean } \\
\text { score }\end{array}$ & Rank & Particulars & Mean score & Rank \\
\hline 1 & $\begin{array}{l}\text { Incidence of pests and } \\
\text { diseases }\end{array}$ & 69.53 & I & Climatic conditions & 73.13 & I \\
\hline 2 & Water problem & 64.98 & II & Decreasing production & 69.88 & II \\
\hline 3 & Shortage of tree climbers & 62.88 & III & Poor quality of produce & 54.38 & III \\
\hline 4 & Financial problem & 42.45 & IV & Financial problem & 48.65 & IV \\
\hline 5 & Climatic condition & 40.53 & $\mathrm{~V}$ & Lack of knowledge of new technology & 44.78 & $\mathrm{~V}$ \\
\hline \multirow[t]{2}{*}{6} & High cost of input & 34.83 & VI & $\begin{array}{l}\text { Lack of proper infrastructure for copra } \\
\text { making }\end{array}$ & 29.68 & VI \\
\hline & Labour problem & 31.83 & VII & Labour problem & 26.53 & VII \\
\hline
\end{tabular}

Table 11: Marketing constraints faced in the study area

\begin{tabular}{|c|c|c|c|c|c|c|c|c|c|}
\hline \multicolumn{4}{|c|}{ Copra makers } & \multicolumn{3}{|c|}{ Wholesalers } & \multicolumn{3}{|c|}{ Retailers } \\
\hline $\begin{array}{l}\text { Sl. } \\
\text { No }\end{array}$ & Particulars & $\begin{array}{l}\text { Mean } \\
\text { score }\end{array}$ & Rank & Particulars & $\begin{array}{l}\text { Mean } \\
\text { score }\end{array}$ & Rank & Particulars & $\begin{array}{l}\text { Mean } \\
\text { score }\end{array}$ & Rank \\
\hline 1 & Price fluctuation & 75.73 & I & $\begin{array}{l}\text { Fluctuation in market } \\
\text { price }\end{array}$ & 72.15 & I & $\begin{array}{l}\text { Fluctuation of market } \\
\text { price }\end{array}$ & 75.08 & I \\
\hline 2 & $\begin{array}{l}\text { World price of } \\
\text { coconut oil }\end{array}$ & 65.68 & II & $\begin{array}{l}\text { Lack of consistent } \\
\text { demand }\end{array}$ & 68.65 & II & $\begin{array}{l}\text { High cost of } \\
\text { transportation }\end{array}$ & 63.20 & II \\
\hline 3 & Bullish pattern & 54.78 & III & $\begin{array}{l}\text { High commission } \\
\text { charges }\end{array}$ & 52.15 & III & $\begin{array}{l}\text { Poor keeping quality of } \\
\text { produce }\end{array}$ & 54.80 & III \\
\hline 4 & $\begin{array}{l}\text { Exploitation by } \\
\text { middlemen }\end{array}$ & 51.63 & IV & $\begin{array}{l}\text { Lack of infrastructure } \\
\text { facilities in the market }\end{array}$ & 46.75 & IV & $\begin{array}{l}\text { High commission } \\
\text { charges }\end{array}$ & 49.35 & IV \\
\hline 5 & $\begin{array}{l}\text { High cost of } \\
\text { transportation }\end{array}$ & 43.15 & $\mathrm{~V}$ & $\begin{array}{l}\text { High cost of } \\
\text { transportation }\end{array}$ & 43.93 & V & $\begin{array}{l}\text { Lack of consistent } \\
\text { demand }\end{array}$ & 47.78 & V \\
\hline 6 & $\begin{array}{l}\text { Lack of market } \\
\text { information }\end{array}$ & 32.13 & VI & Poor quality produce & 38.40 & VI & $\begin{array}{l}\text { Lack of market } \\
\text { information }\end{array}$ & 29.63 & VI \\
\hline 7 & $\begin{array}{l}\text { In-adequate } \\
\text { storage facility }\end{array}$ & 23.93 & VII & $\begin{array}{l}\text { Lack of market } \\
\text { information }\end{array}$ & 24.58 & VII & Distant market place & 27.18 & VII \\
\hline
\end{tabular}

Majority of the retailers expressed the major problem (Table 11) were fluctuation of market price followed by high cost of transportation, poor keeping quality of produce and high commission charges in the study area. It was observed that most of the retailers expressed the lack of consistent demand, lack of market information and distant market place were the minor problems and they have been assigned lower ranks.

These results revealed that fluctuation in market price was considered as major problems for both wholesalers and retailers in the study area. The results of the study are in line with the research conducted by Nagaraju (2013).

\section{CONCLUSION AND POLICY IMPLICATIONS}

The present study indicated that the performance of palm industry in Karnataka. The total establishment cost of coconut orchard was estimated at ₹ $1,58,842.82$ per acre. The annual cost of cultivation of coconut was ₹ 55,933.91 per acre. Due to monsoon failure, lack of irrigation facilities and less market price they incurred loss in coconut production. The total cost incurred in copra making from 5,777.65 nuts estimated at $₹ 69,400.33$ and obtained 8.86 quintal of copra. Copra making in the study area is a profitable venture as indicated by benefit cost ratio (1.68). Three important marketing channels identified in the study area among these, channel III found to be more efficient than other channels in the market. Majority of the copra makers expressed that drastic climate change lead to decrease in production, fluctuation in price of coconut oil was the major marketing problem. The other problem faced by wholesalers was lack of consistent demand and in case of retailers high cost of transportation was the major problems. To overcome these problems 
government can promote artificial dryer unit under cooperative sector, as traditional method of copra making consuming more time and it can provide financial help to construct proper infrastructure for coconut storing unit. Creating awareness to encourage online trading for better price realization for copra makers and better quality is the need of the hour. The copra manufactured in the study area was of good quality. Hence, efforts should made to export the copra.

\section{REFERENCES}

Anonymous, 2016. Horticulture crop statistics of Karnataka state at a glance.

Kakkali, M. 2013. A study on marketing of raisin in Bijapur district, Project Report submitted to the UAS, Bangalore.

Kishore M.S. and Murthy C. 2017, Economic feasibility of coconut cultivation in Karnataka. International Journal of Commerce and Business Management. 10(2): 243-249.

Kerutagi M.G., Deshetti B.M. and Abhilash K. 2017. Comparative economics of traditional Viz high density mango cultivation in Karnataka. Asian Journal of Agricultural Extension, Economics and Sociology, 18(3): 1-12.

Murthy B.V.R.K. 1999. The economy of coconut in East Godavari district of Andhra Pradesh. M.Sc. (Ag) thesis submitted to Acharya N.G. Ranga Agricultural University, Rajendra Nagar, Hyderabad.
Mabel Sulochana, R. 2009. Production and marketing of coconut with special reference to Kanyakumari district. $\mathrm{PhD}$ in commerce thesis submitted to Manonmaniam Sundaranar University, Tamil Nadu.

Namasivayam, N. and Paul Richard, V. 2006. Price spread in marketing of coconut in Tamil Nadu. Indian Journal of Marketing, 36(7): 3-5.

Nagaraju, M.C. 2013. A study on consumer preference and competitiveness for Tiptur copra in selected cities of North India, M.Sc (Ag) thesis submitted to UAS, Bangalore.

Narendr Kumar Meena, Naik, S.S., Ratnaparkhe, A.N., Rajesh Kumar and Gurjar, G.N. 2017. A study of marketing of coconut in Raigad district of Maharashtra. International Journal of Agriculture Sciences, 9(12).

Hasna Hassan, P.P. 2010. An economic analysis of arecanut production in Malappuram district of Kerala, M.Sc. (Agri.) thesis (unpublished) Submitted to Acharya N.G. Ranga Agricultural University.

Remold, M. 2000. Cost benefit analysis of coconut cultivation (Rainfed). Indian Coconut Journal, 31(3): 7-9.

Srinivas, I.K. 1989. An economic analysis of production and marketing of coconut in East Goadavari district of Andhra Pradesh M.Sc. (Ag) thesis submitted to Andhra Pradesh Agricultural University. Hyderabad.

Sairam, C.V., Gopalasundaram, P., Muralidharan, K., George, M.V., Hedge, M.R. and Umamaheswari, L. 1997. Estimation of cost of production of coconut under optimum management conditions in North Kerala. Journal of Plantation Crops, 25(2): 163-16. 